\title{
21. Taming Leadership? Adapting to Institutional Change in New Zealand Politics
}

\section{Raymond Miller}

\section{Introduction}

Studies of political leadership typically place great stress on the importance of individual character. The personal qualities looked for in a New Zealand or Australian leader include strong and decisive action, empathy and an ability to both reflect the country's egalitarian traditions and contribute to a growing sense of nationhood. The impetus to transform leaders from extraordinary people into ordinary citizens has its roots in the populist belief that leaders should be accessible and reflect the values and lifestyle of the average voter. This fascination with individual character helps account for the sizeable biographical literature on past and present leaders, especially prime ministers. Typically, such studies pay close attention to the impact of upbringing, personality and performance on leadership success or failure.

Despite similarities between New Zealand and Australia in the personal qualities required of a successful leader, leadership in the two countries is a product of very different constitutional and institutional traditions. While the overall trend has been in the direction of a strengthening of prime ministerial leadership, Australia's federal structure of government allows for a diffusion of leadership across multiple sources of influence and power, including a network of state legislatures and executives. New Zealand, in contrast, lacks a written constitution, an upper house, or the devolution of power to state or local government. As a result, successive New Zealand prime ministers and their cabinets have been able to exercise singular power.

This chapter will consider the impact of recent institutional change on the nature of political leadership in New Zealand, focusing on the extent to which leadership practices have been modified or tamed by three developments: the transition from a two-party to a multi-party parliament, the advent of coalition government, and the emergence of a multi-party cartel. The chapter will conclude by posing three questions. First, is it possible to construct a conceptual framework that captures the impact of institutional change on political leadership in New Zealand? Second, given the importance of managerial competence to the success of coalition government, how transferable are the skills of party leader to those of prime minister? And third, given the constraining influence of an active and 
engaged public on political parties, should the major party leaders be elected by the MPs, as at present, or by the wider party membership?

\section{Political leadership and institutional change}

In his study of ethics in Australian government, John Uhr argues that political leadership can be dispersed and power tamed by a process of institutional checks and balances. Key elements in this process may include: the devolution of power to the state governments, public re-engagement with political parties, a stronger parliament, and ministerial government based on decision-making by consensus (Uhr 2005: 78-87). The resulting 'lattice of leadership' provides an alternative to the concentration of power in the hands of small and self-interested national elites. Although any such proposals are heavily prescriptive, it has been argued that constraining the powers of political leaders and increasing the opportunities for public and community participation produces a more diffused and, therefore, more accountable leadership (Walter and Strangio 2007: 64-85).

During the 1980s and 1990s, politics in New Zealand was marked by growing public opposition to the governing elite, especially over the pace and magnitude of neo-liberal reform. One consequence was the rise in support for small parties - by 1993 almost one third of all voters had begun to cast their votes for the growing array of small parties. A related but even more important consequence of voter disillusionment was the decision by national referendum to replace the existing plurality electoral system with proportional representation (PR). The prospect that National and Labour would be required to share legislative and executive power with the small parties was greeted with alarm by the major party leaders, notably National's Jim Bolger and Jenny Shipley, and Labour's Helen Clark. During the referendum campaign they warned voters that proportional representation would result in legislative paralysis and unstable government. Bolger, who was prime minister at the time, even suggested the alternative of an upper house, an idea that was roundly rejected by the voting public.

Among the subsequent institutional changes that have had a direct bearing on political leadership in New Zealand - offering the prospect that a 'lattice of leadership' would begin to emerge - three stand out.

\section{Proportional representation: leadership through legislative bargaining}

One of the most notable features of the new proportional system has been the sheer number of parties winning parliamentary seats. Apart from the occasional presence of a Social Credit MP, throughout the post-war period the only parties holding seats were National and Labour. In contrast, as a result of an electoral system that awards seats in proportion to a party's share of the vote, a total of eight parties sat in the 2005-2008 Parliament. Because this has resulted in minority 
government, the prime minister has had to keep the lines of communication open with each and every opposition party. This has left Labour in the difficult position of having to turn to its old adversary, National, for support in passing some important legislation, including the Singapore free trade agreement (2000), the controversial anti-smacking legislation (2007), and the NZ-China free trade agreement (2008).

Despite the proliferation of parliamentary parties, the actual number is less relevant to the theme of this chapter than the potential bargaining power each exercises within parliament and government. While some opposition parties are unashamedly opportunistic and pragmatic, others continue to harbour deep ideological and personal grudges dating back to the neo-liberal reforms of the 1980s and early 1990s. Their leaders have even been described as 'political agitators, who thrive on conflict, are often narcissistic and possess an unbending belief in the virtue of their cause' (Miller 2006: 116). These character traits would have little significance were it not for the fact that, in the context of a multi-party parliament, small parties are often veto players, as illustrated by the conduct of the Greens when, in 2002, they threatened to bring the Clark government down the moment it lifted its moratorium on the release of genetically modified corn. While adopting such a hard-line position can bring much-needed media attention, there are some inherent risks: veto players that exceed their powers not only endanger relations with the other parties (as a result of the Greens' decision, Clark decided to exclude them from the next government), but also the voting public.

\section{Coalition government: leadership through inclusion and compromise}

A further set of institutional changes impacting on political leadership concerns the transition from a single-party to a coalition government. Unlike Australia's Liberal-National Coalition, which is a permanent arrangement, one or other of New Zealand's two major parties must build a fresh coalition after each and every election. Thus, while the powers of the prime minister have been reduced, the range of strategic and interpersonal skills are much greater than they were when prime ministers enjoyed the benefit of both a guaranteed majority and a full slate of ministerial portfolios with which to reward their MPs. Following the 1993 election, the last under plurality voting, Prime Minister Jim Bolger had the luxury of some 30 executive positions to share amongst his 49 caucus colleagues. In contrast, following the first election under PR, the same prime minister was forced to sacrifice five of his 20 cabinet positions to the junior coalition partner, New Zealand First, with the promise of three additional positions within the term of that government. Lack of ministerial opportunities caused several of Bolger's colleagues to complain that he had 'sold out' to New Zealand First. Within a year, he was replaced as party leader and prime minister. 
Successful coalition leadership requires levels of consultation, compromise and inclusiveness barely comprehended a decade or more ago. Although the first coalition failed to survive the fractious personal relationship that existed between Prime Minister Shipley and the New Zealand First leader, Winston Peters, the following three coalitions, all led by Labour, have been remarkably stable and effective. Much of the credit for that success is due to Clark's relentless pragmatism, as well as her skill as a micro-manager. This was especially so during the fraught coalition negotiations process, but is also true in day-to-day relations with the other party leaders - on occasions over a cup of tea, as with the Green co-leader, Jeanette Fitzsimons, and on others more formally. Relations between the coalition partners have been further aided by an agree-to-disagree amendment to the Cabinet Manual. It gives small governing parties the ability to oppose certain cabinet decisions without bringing down the government. This provision was first used by the Alliance in 2000 to oppose the government's free trade agreement with Singapore.

The complex nature of coalition arrangements is best illustrated with reference to the 2005-08 (minority) government. At the 2005 election Labour won 50 seats, 11 seats short of an overall majority. Although the willingness of the Progressive (1) and Green (6) parties to join a Labour-led coalition was assured, this combined centre-left bloc failed to offer Clark the parliamentary majority needed to pass legislation. To complicate matters, the two centre parties, New Zealand First (7) and United Future (3), made it clear that they would not support a government that included the Greens (both argued that the Greens were unreliable and their views extreme). New Zealand First's position was further complicated by the fact that, in the lead-up to the election, Peters had promised voters that his party would not be part of the next government, regardless of whether it was led by Labour or National. Labour's only other possibility was an agreement with the Maori Party (4), an unlikely proposition given the small party's opposition to the government's Foreshore and Seabed legislation. Feelings were mutual, with the prime minister promising during the campaign that, when it came to negotiating a coalition, the Maori Party would be 'the last cab off the ranks'.

The creative compromise to this dilemma was to exclude the Greens from any coalition arrangement, and instead offer both Peters and United Future's Peter Dunne ministerial positions, ostensibly outside of government. In giving Peters the prestigious Foreign Affairs portfolio and Dunne Revenue, Clark provided each party with the barely plausible argument that, while they represented the government (Peters internationally) they were not to be regarded as members of the government (under the terms of their agreement, both party leaders were permitted to oppose the government on all matters outside their portfolios). Having promised that he would not be seduced by the 'baubles of office', Peters was especially vulnerable to the accusation that he had deliberately misled his party's members and voters. To finalise this complex multi-party arrangement, 
separate agreements had to be reached with each of the coalition and support parties, with the Progressives signing a full coalition agreement, New Zealand First and United Future separate 'Confidence and Supply' agreements, and the clearly disappointed Greens a 'Cooperation' agreement. The speed and effectiveness with which the prime minister finalised these arrangements are testimony to her negotiating and management ability.

The extent to which the prime minister's powers have been curbed by the advent of coalition government can be illustrated with respect to the NZ-China free trade agreement. Shortly before the agreement was signed in April 2008, Dunne reversed his earlier decision to accompany the New Zealand delegation to Beijing in protest at the Chinese government's repression of Tibetan protestors (although his party was prepared to support the agreement in Parliament). Peters went a step further in announcing that his party would vote against the pact on the grounds that it did not provide enough benefits for New Zealand. While successful passage of the agreement was never at risk (it had the support of five parties, including National), the Foreign Minister's announcement provoked calls for his resignation. In response, Labour denied any hypocrisy in having the Foreign Minister publicly oppose New Zealand's most significant free trade agreement. After all, as Clark herself admitted, 'Winston Peters has made it possible for us to govern'.

\section{Cartel parties: leadership through personalisation}

A third institutional change that bears on the question of the taming of political leadership concerns the party system itself, specifically the evolution from the mass and catch-all stages of party organisation to that of a cartel (Katz and Mair 1997). While much of the theoretical work on this latter model has focused on the major parties, especially the extent to which they collude over the distribution of the material resources of the state, recent experience in New Zealand points to the existence of multi-layered cartels, with the dispersal of some of the spoils of office to small parties (but only inside parliament), especially those with the potential to keep one or other of the major parties in power. These resources are said to include material support for party (as distinct from parliamentary) activities, including the free use of office space, air travel, staffing, advertising, and professional and consultancy services.

More recent work on cartels (Blyth and Katz 2005) has extended the argument beyond the use of material resources to include anti-competitive measures with respect to the ways the two major parties occupy the ideological and policy space. According to this view, the established parties are less inclined to compete over policy differences, preferring to appeal to the amorphous 'median' voter. Blyth and Katz argue that, through a combination of free market reform and economic globalisation, most of the policy competition has been 'maxed out'. Paralleling developments in the United Kingdom, Australia and elsewhere, New 
Zealand is experiencing growing policy agreement. While parties continue to present themselves as bitter and uncompromising rivals during election campaigns, substantial policy disagreement has all but disappeared. In the case of New Zealand, this can be illustrated with reference to the commitment of Labour and National to broadly similar policies on social spending, especially health and education, taxation rates (both support cuts), nuclear power, climate change and the war in Iraq.

In the absence of policy difference, under the cartel model the major parties now stress their 'managerial competence' and 'personal' style of leadership. New Zealand's political leaders were once recruited from the ranks of the farming and small business communities, as well as the unions. During the past two decades these leaders have been replaced by a new generation of highly educated and professionally trained technocrats. Examples of this 'embourgeoisement' of leadership (Kavanagh 1990: 107) include David Lange (lawyer), Geoffrey Palmer (law professor), Clark (university lecturer), Bill English (economist), Don Brash (Reserve Bank Governor), and John Key (currency trader).

\section{Understanding and adapting to institutional change: leadership challenges}

\section{Understanding the leadership impact of institutional change}

One approach to the study of leadership is the quasi-psychoanalytic method pioneered by James David Barber (1972). While John Henderson's work on New Zealand prime ministers borrows heavily from this model, and makes a number of useful observations about leadership under PR, Barber's highly deterministic and arbitrary schema fails to capture the essence of leadership in a Westminster parliamentary system. One of the most helpful aspects of Henderson's work, however, is his four categories of leader: achievers, power-seekers, reluctants and performers (1992). A second and potentially more useful approach has been offered by Dennis Kavanagh (1990) in his work on British prime ministers. Building on James McGregor Burns' distinction between transformational and transactional leadership, Kavanagh proposes a cyclical typology containing two styles of leadership: mobilising leadership and excessive, or reconciling, leadership. 'Mobilising' leadership may be required in times of national crisis or when there is a need for radical reform. 'Excessive' leadership, on the other hand, comes into prominence when there is need for greater social cohesion and consensus, typically after the destabilising premiership of a mobilising leader. While this model works well in single party governments such as that of the United Kingdom, it has less value when applied to coalition democracies, where the emphasis on co-operation, compromise and consensus is unlikely to be cyclical, but rather continuous. 
Combining features of these two models, this chapter proposes a functional model that identifies the three distinct sets of characteristics or leadership styles required of a New Zealand politician. While leaders are called upon to exercise all three functions, the model calls for an overall judgment about the characteristic that most distinguishes that person's style of leadership. Mobilisers are the great performers who use the channels of mass communication to inspire and persuade others to be their followers. In a parliamentary system, such politicians must display a range of skills, including extempore public speaking and debating. Examples of mobilising politicians are David Lange and Winston Peters. Legislators, on the other hand, are the analytical thinkers who not only have a detailed grasp of public policy, but have the ideological commitment and tenacity to see it enacted. Unlike Mobilisers, Legislators are often prepared to sacrifice personal popularity and ambition for the sake of principle. While Lange was a superb salesman for the government's free market reforms, Roger Douglas, Geoffrey Palmer and David Caygill were its architects.

The third category of leaders, and the one most appropriate to the behaviour of prime ministers in a PR environment, are the Managers. Unlike the Mobilisers, who practice the power of mass persuasion, and the Legislators, who achieve transformational change, Managers are the pragmatists who value consultation and compromise, and who appreciate that decisions are forged through hard-fought trade-offs with political allies and adversaries. In short, the Manager 'must balance the needs of a complex array of frequently competing groups, including consultants, advisers, cabinet colleagues, coalition partners, backbench MPs, public servants and the voting public' (Miller and Mintrom 2006: 5). Examples of Managers include some of New Zealand's most successful and long-term prime ministers, notably Peter Fraser, Keith Holyoake and Helen Clark.

\section{From party mobiliser to coalition manager: the new prime ministership}

Under the former two-party system, the transition from opposition leader to prime minister was relatively straightforward. As guardians of the party's ideology, party leaders were expected to be highly programmatic and partisan, even dogmatic. Those who became prime minister were able to behave in much the same manner, thanks to a parliamentary majority and absence of veto players, notably the minor parties and independents. Cabinet had to be managed, but there was little need to consult or compromise with the Opposition, thus ensuring that relations remained as robust during the parliamentary term as they had been in the campaign. As McLeay has pointed out, while the role of party leader is largely unchanged, 'MMP [PR] has meant that an effective prime minister can transcend party allegiance in a way that was not possible when leaders and followers were either inside or outside of government, and politics was entirely a zero-sum game' (2006: 109). Within days of an election, competitors morph 
into allies, and policies once firmly rejected are incorporated into the government's legislative agenda. Because it requires a mixture of guile and good grace, the role of prime minister is quickly transformed from that of mobilising party leader to reconciling coalition manager. This is not to suggest that the leader of a coalition has to be pliant to be effective; in fact, Clark's style of leadership is frequently depicted in the media as strong, unbending, and even ruthless.

\section{Implications for party leadership selection}

Defenders of the highly centralised system of leadership selection practised in New Zealand and Australia argue that those closest to the action are best able to assess the relative merits of prospective leaders. They may draw on survey data showing that party delegates and members, and even more so voters, lack knowledge of the internal dynamics of their parliament and government. While they may be well placed to evaluate the mobilising powers of aspiring leaders, especially by observing an election campaign, they are clearly less competent to judge legislative and managerial competence. To accusations of elitism, they are likely to respond that MPs worth their salt will canvass opinion among grassroots party members before voting for the leader.

On the other hand, those who advocate a more democratic selection process argue that ordinary citizens can compensate for any lack of institutional knowledge by bringing a detached and less self-interested approach to their decision. They might also warn against trying to anticipate how people will respond to the challenge of leadership, as illustrated by the selection of Clark as party leader in 1993. At the time she became leader, Clark was in open conflict with the Alliance leader, Jim Anderton, mainly over his split with Labour in 1989. Between 1993 and 1996 relations between the two continued to deteriorate to a point where any prospect of a coalition agreement had all but disappeared. It was this tough, take-no-prisoners approach to leadership that helped make Clark such an appealing prospect as leader. Those MPs who voted for her could hardly have predicted that her reputation as prime minister would be built on an ability to work closely in government with Anderton, for three years her deputy prime minister, as well as with parties as ideologically distant from Labour as United Future and New Zealand First.

Perhaps the most satisfactory outcome to this debate would be to find a compromise similar to that reached by the British Conservative and Liberal Democrat parties. It grants MPs the right to provide a shortlist of potential leaders, with party delegates or members making the final selection.

\section{Conclusion: a robust trend?}

As this chapter has argued, leadership practices in New Zealand have been significantly modified or tamed by institutional change. Whilst the prime minister 
and executive continue to be the pre-eminent political actors, the trend towards minority government has produced a discernible shift in the balance of power towards the multi-party legislature and its increasingly independent select committees. With the emergence of veto players, mainly in the form of the small parties, the role of prime minister is being transformed from that of mobilising party leader to reconciling coalition manager.

Whether these constraints on prime ministerial leadership prove durable is a matter of some conjecture. The currently low levels of public support for small parties point to the possibility of a substantial shrinking in their number and influence in the years ahead. In the event that this occurs, and that there is a return to a single party majority government, will the more consultative and constrained style of prime ministerial leadership prevail, or will there be a return to the leadership practices of the pre-PR era? Only time will tell.

\section{References}

Adams, D., 2002, 'The Leadership Contest', in J. Warhurst and M. Simms (eds), 2001: The Centenary Election, St Lucia: University of Queensland Press, pp. 19-32.

Barber, J. D., 1972, The Presidential Character: Predicting Performance in the White House, Englewood Cliffs: Prentice-Hall.

Blyth, M. and R. Katz, 'From Catch-all Politics to Cartelisation: The Political Economy of the Cartel Party', West European Politics, 28:1, pp. 33-60.

Capie, D., 2006, 'Constructing New Zealand in the World', in R. Miller and M. Mintrom (eds), Political Leadership in New Zealand, Auckland: Auckland University Press, pp. 17-32.

Henderson, J., 1992, 'Labour's Modern Prime Ministers and the Party: A Study of Contrasting Political Style', in M. Clark (ed.), The Labour Party After 75 Years, Wellington: Victoria University Press, pp. 98-117.

Katz, R. and P. Mair, 1997, 'Party Organisation, Party Democracy, and the Emergence of the Cartel Party', in P. Mair, Party System Change: Approaches and Interpretations, Oxford: Oxford University Press, pp. 93-119.

Kavanagh, D., 1990, Politics and Personalities, London: MacMillan.

McLeay, E., 2006, 'Leadership in Cabinet Under MMP', in R. Miller and M. Mintrom (eds), Political Leadership in New Zealand, Auckland: Auckland University Press, pp. 92-112.

Miller, R. and M. Mintrom (eds), 2006, Political Leadership in New Zealand, Auckland: Auckland University Press, pp. 113-132. 
Miller, R., 2006, 'Minor Party Leadership Under Proportional Representation', in R. Miller and M. Mintrom (eds), Political Leadership in New Zealand, Auckland: Auckland University Press, pp. 113-132.

Palmer, G., 1987, Unbridled Power: An Interpretation of New Zealand's Constitution and Government, $2^{\text {nd }}$ edition, Auckland: Oxford University Press.

Uhr, J., 2005, Terms of Trust: Arguments Over Ethics in Australian Government, Sydney: University of New South Wales Press.

Walter, J. and P. Strangio, 2007, No, Prime Minister: Reclaiming Politics from Leaders, Sydney: University of New South Wales Press. 